Violette Nozière 
This page intentionally left blank 


\section{Violette Nozière}

A STORY OF MURDER IN I93OS PARIS

Sarah Maza

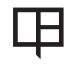

U NIVERSITY OF CALIFORNIA PRESS BERKELEY LOS ANGELES LONDON 
University of California Press, one of the most distinguished university presses in the United States, enriches lives around the world by advancing scholarship in the humanities, social sciences, and natural sciences. Its activities are supported by the UC Press Foundation and by philanthropic contributions from individuals and institutions. For more information, visit www.ucpress.edu.

University of California Press

Berkeley and Los Angeles, California

University of California Press, Ltd.

London, England

(C) 20Ir by The Regents of the University of California

Library of Congress Cataloging-in-Publication Data

Maza, Sarah C., 1953-

Violette Nozière : a story of murder in I930s Paris /

Sarah Maza.

p. $\mathrm{cm}$.

Includes bibliographical references and index.

ISBN 978-0-520-26070-2 (cloth : alk. paper)

I. Nozière, Violette, I915-I966. 2. Women murderers-France-Paris-Biography. 3. MurderFrance-Paris-Case studies. 4. Women-FranceParis-Social conditions-2oth century. 5. Paris

(France)-Social conditions-2oth century. I. Title. HV6248. $\mathrm{N}_{7} \mathrm{M}_{39} 2 \mathrm{2OII}$

364.I52'3092-dc22 2010028603

Manufactured in the United States of America

$\begin{array}{llllllllll}20 & \text { I9 } & \text { I8 } & \text { I7 } & \text { I6 } & \text { I5 } & \text { I4 } & \text { I3 } & \text { I2 } & \text { II }\end{array}$

IO $\quad 9 \begin{array}{lllllllll} & 9 & 7 & 6 & 5 & 4 & 3 & 2 & \text { I }\end{array}$

This book is printed on Cascades Enviro Ioo, a Io०\% post consumer waste, recycled, de-inked fiber. FSC recycled certified and processed chlorine free. It is acid free, Ecologo certified, and manufactured by BioGas energy. 
FOR JULIETTE 
This page intentionally left blank 